\title{
STRATIGRAPHY OF THE LOWER TERTIARY ROCKS OF NEPAL
} HIMALAYA

\section{N. B. Kayastha}

Petroleum Exploration Project, Department of Mines \& Geology

Lainchaur, Kathmandu

\section{ABSTRACT}

The Lower Tertiary rocks of Nepal Himalaya are classified under the Surkhet Group which comprises Melpani, Swat and Suntar Formations. ( Paleocene - Lower Miocene). There is perfect stratigraphic harmony between Surkhet Group and underlying Metasediments of Mahabharat Group, Lesser Himalaya ( PalaeozoicMesozoic ) with an unconformity. Correlation of the Lower Tertiary rocks of Nepal, India, Pakistan, and their European and North American equivalents is tabulated (Table 2).

\section{INTRODUCTION}

Stratigraphy of the Lower Tertiary rocks of Nepal has not been studied well so far. The present work has made an effort to establish the stratigraphy of the Lower Tertiary rocks based on geological investigation around Surkhet, Jajarkot, Dang, Piuthan, Sallyan, Rolpa and Tansen areas. The Surkhet Group has rocks ranging in age from Paleocene to Lower Miocene. The upper limit of the group is always truncated by a thrust, named as Ranimatta/Dibidanda thrust. The lower limit has an unconformable contact with the different members of the Lakharpata and the Sangram Formations of the Mahabharat Group (Palaeozoic to Mesozoic). The Surkhet Group has been classificd into the Melpani, Swat and Suntar Formations based on lithological and palcontological assemblages ( Tater et. al 1982). A generalised composite columnar section of Lower Tertiary rocks of the Nepal Himalaya is presented (Figure 2).

\section{DISTRIBUTION OF OUTCROPS}

The Lower Tertiary rocks (Paleocene- Lower Miocene) is well exposed at several places in Nepal Himalaya (Figure 1), however its best development has been recorded in Surkhet, Dang and Tansen area, Western Nepal. The Lower Tertiary exposures are lenticular in shape and found to extend from the sharp bent of Karnali River in the west to east of Dang valley. The repeatition of Lower Tertiary rocks up to six times are noted in the Dang area on account of tight folding and thrusting. Scattered outcrops are found in Jajarkot and Sallyan areas with East- West and North- South trend along the thrust zone. Its exposure is also distributed almost continuously on the both flanks of Tansen Synclinorium. In Central and Eastern Nepal, the Lower Tertiary rocks are not expossed.

\section{STRATIGRAPHY}

A complete stratigraphic succession of the Lower Tertiary rocks of Nepal Himalaya includes the Surkhet group which comprises the Melpani, Swat and Suntar Formations ( Paleocene- Lower Miocene). 


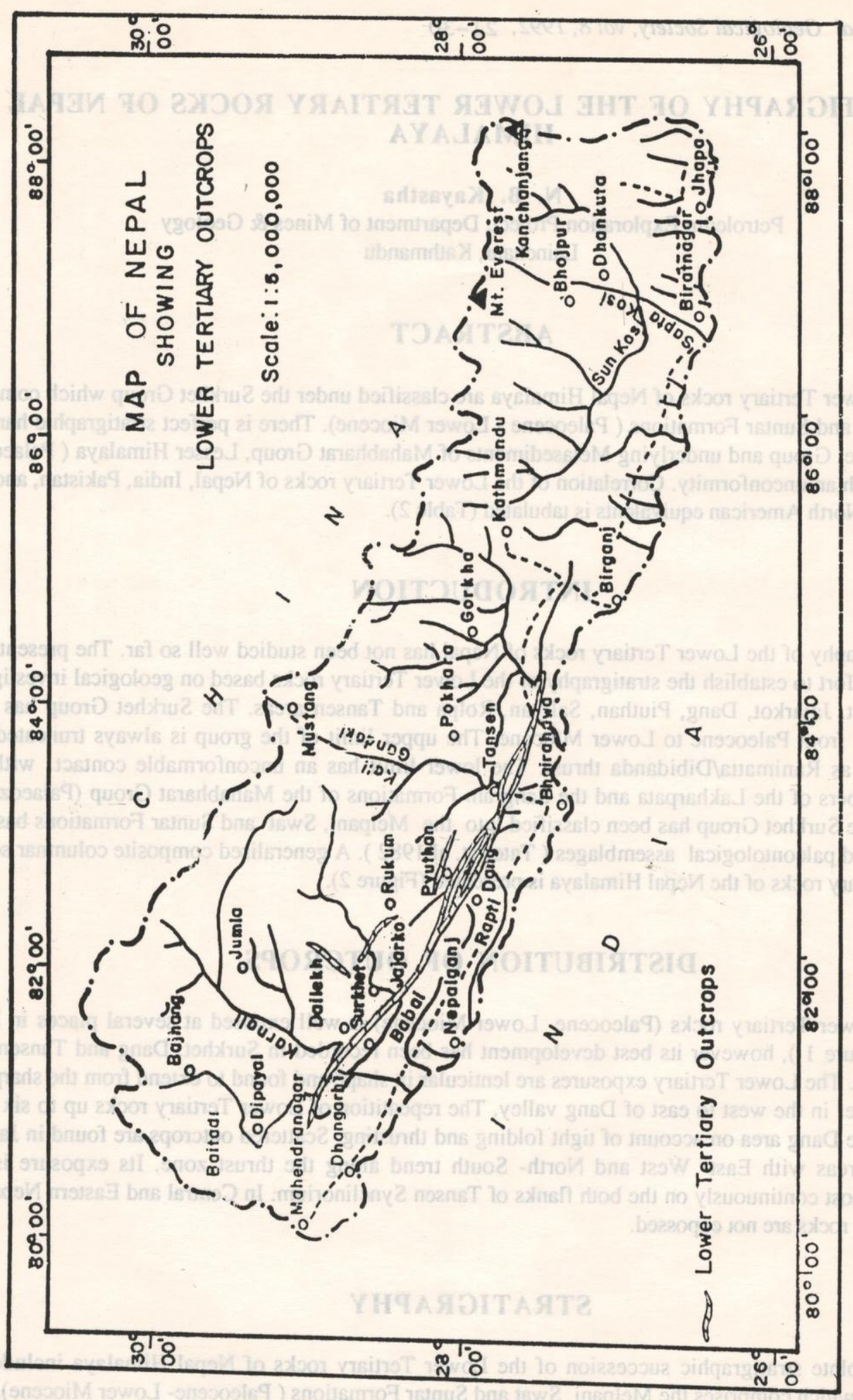

告 


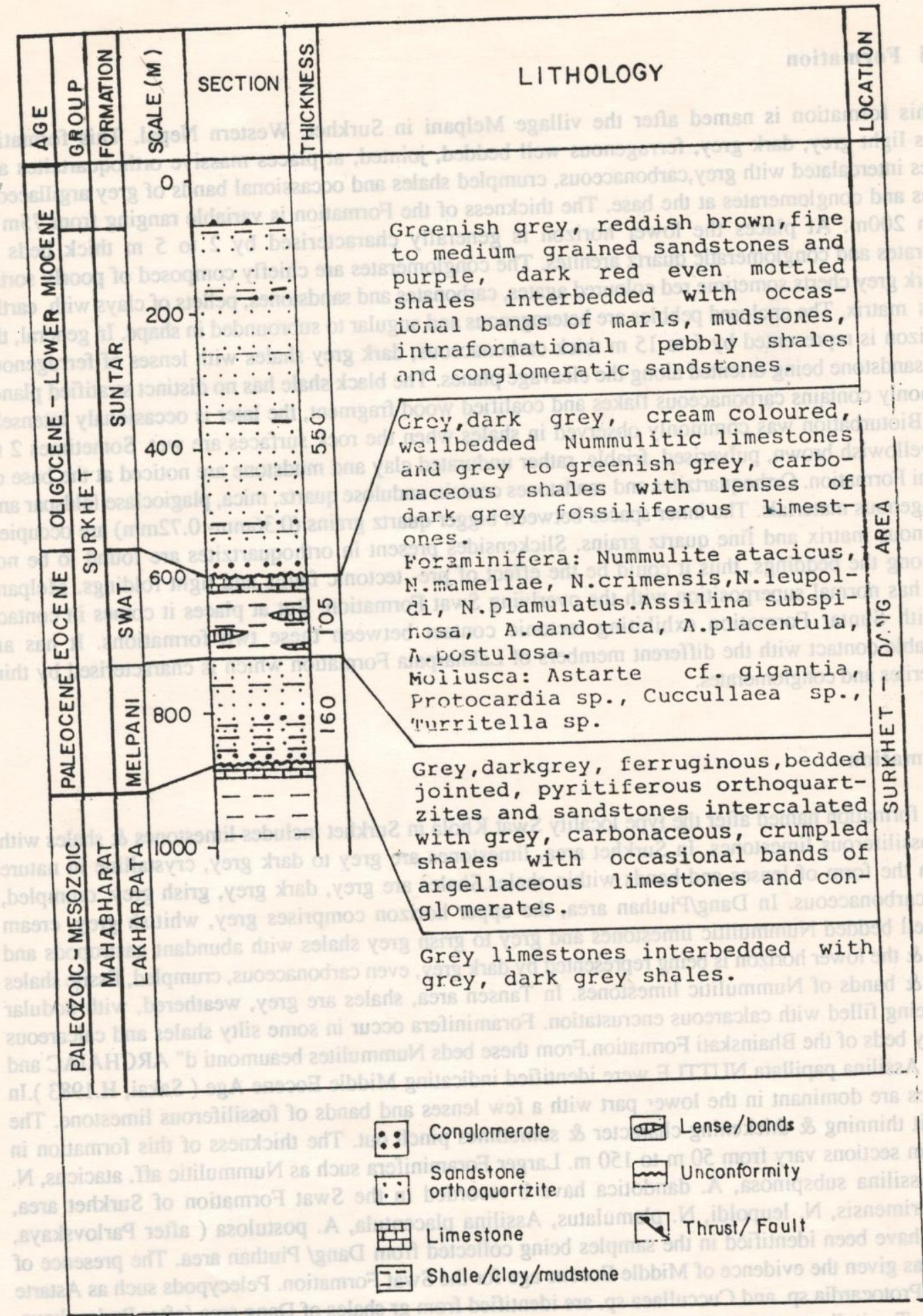

Figure 2 Generalised composite columnar section 


\section{Melpani Formation}

This formation is named after the village Melpani in Surkhet, Western Nepal. This formation comprises light grey, dark grey, ferrugenous well bedded, jointed, at places massive orthoquartzites and
sandstones intercalated with grey,carbonaceous, sandstones intercalated with grey,carbonaceous, crumpled shales and occassional bands of grey argillaceous
limestones and conglomerates at the base. The thickness of the Formation is maximum $200 \mathrm{~m}$. At places the lower horizon is thess of the Formation is variable ranging from $75 \mathrm{~m}$ to conglomerates and conglomeratic quartz arenites. The grey to dark grey cherts sometime red coloured agates, conglomerates are chiefly composed of poorly sorted calcareous matrix. The enclosed pebbles are heterogenous and angandstones, pellets of clays with earthy lower horizon is represented by 5 to $15 \mathrm{~m}$ thick carbonaceous, quartzose sandstone being oriented along the cleavage planes. The grey shales with lenses of ferrugenous and commonly contains carbonaceous flakes and coage planes. The black shale has no distinct stratified planes pyritized. Bioturbation was commonly observed in shales wood fragment, the later is occasionaly intensely $5 \mathrm{~m}$.thick yellowish brown, pulverised, friable, in shales when the rock surfaces are wet. Sometimes 2 to the Melpani Formation. Orthoquartzites and sandster undurated clay and mudstone are noticed at the base of some ferrugenous materials. The inner spaces between contain undulose quartz, mica, plagioclase feldspar and by ferrugenous matrix and fine quartz grains. Slickensides quartz grains $(0.36 \mathrm{~mm}-0.72 \mathrm{~mm})$ are occupied oriented along the beddings, thus it could be the effect of present in orthoquartzites are found to be not Formation has normal superposition with the overlying of pre- tectonic faults and tight foldings. Melpani directly with Suntar Formation exhibiting tectonic Swat Formation. But at places it comes in contact unconformable contact with the different members of contact between these two formations. It has an layer of laterites and conglomerates.

\section{Swat Formation}

This formation named after the type locality Swat Khola in Surkhet includes limestones \& shales with lenses of fossiliferous limestones. In Surkhet area, limestones are grey to dark grey, crystalline in nature
occurring in the form of lenses and occurring in the form of lenses and bands within shales.Shales are grey, dark grey, grish grey, crumpled,
sometimes carbonaceous. In Dang/Piuthan area, the coloured, well bedded Nummulitic limestones and the upper horizon comprises grey, whitish grey, cream pelecypods, \& the lower horizon is being represented by do grish grey shales with abundant gastropods and with lenses \& bands of Nummulitic limestones. In by dark grey, even carbonaceous, crumpled, fissile shales characters being filled with calcareous encrustation. Fansen area, shales are grey, weathered, with nodular concretionary beds of the Bhainskati Formation.From Foraminifera occur in some silty shales and calcareous HEIME and Assilina papillata NUTTLE were idom these beds Nummulites beaumonti d" ARCHAIAC and general shales are dominant in the lower part with a few icating Middle Eocene Age ( Sakai, H.1983 ).In shales exhibit thinning \& thickening character \& sometimes pinch bands of fossiliferous limestone. The various stream sections vary from $50 \mathrm{~m}$ to $150 \mathrm{~m}$. Larger Foraminifout. The thickness of this formation in mamellae, Assilina subspinosa, A. dandotica have b recorded in such as Nummulitic aff. atacicus, N. Nummulite crimensis, N. leupoldi, N. plamulatus, Assilina placentu Swat Formation of Surkhet area, 1981 USSR) have been identified in the samples being collected fruma, A. postulosa ( after Parlovskaya, such fossils has given the evidence of Middle Eocene age forled from Dang/ Piuthan area. The presence of cf. gigantica, Protocardia sp. and Cuccullaea sp. are identifier the Swat Formation. Pelecypods such as Astarte 1981, USSR). Turritella sp. are well noticed in Surkhet as from gr shales of Dang area (after Parlovskaya, Investigation Team ( CPIT, 1973) has identified the following fossils fansen area. The Chinesse Petroleum 
Foraminifera - Nummulites aff. atacicus Leymerie,N. cf. mamille ( Fichtel and Moll ), Assilina spinosa Davies, A. subspinosa Davies, A. laminosa Gill.

Bivalvia - Cordiopsis cf.incrassata Sowerby, Cordiopsis sp., Euphenax aff.jamaicensis (Trechmann), Septifer cf. denticulatus (Lamarck), Tellina sp., Dimya aff. deshaysiana Rouault, Oatrea (? Flemingostrea) cf. flemingi d" Archiac and Haime, Botula sp., Corbula cf. daltoni Cotter,Cardita mutabilis d"Archiac and Haime.

Gastropoda - Limacina cf. pseudopyamaea Eames, Volutilithes sp., Turritella cf. hollandi Crossmann and Pissarro. These fossils indicate the age ranging from Middle Eocene to Upper Eocene. The contact with the overlying Suntar Formation has a distinct erosion surface and an abrupt change of lithofacies. At places Swat Formation shows sheared carbonaceous materials at the base suggesting the contact betw Swat and Melpani a tectonic one.

\section{Suntar Formation}

The Suntar Formation is named after the Suntar Khola in Surkhet which comprises alternate sequence of sandstones and shales intercalated with marl bands. Sandstones are generally grish grey and reddish brown in colour. They are hard, fine to medium grained while the shales are purple in colour. Generally, sandstones have rounded to subrounded, well sorted detrital quartz cemented in sericite and argillaceous matrix. Sandstones are highly fractured and jointed. Some beds of sandstones exhibit wedge- shaped cross bedding but those as much as a few metres thick are generally massive and scarcely has suratification planes.Ripple marks are recognized on the surface of the bedded sandstones.There are also intraformational shale pebble conglomerate and conglomeratic sandstones at the basal part of the sandstone beds.Bioturbation is common in shales and is easily recognised by mottled structures or sineous tubes. The individual bed of sandstone varies from $15 \mathrm{~m}$.to $20 \mathrm{~m}$., where as shales differ from $5 \mathrm{~m}$.to $10 \mathrm{~m}$. Within purple shales, reddish brown coloured marl bands and lenses are frequently encountered in Surkhet, Dang/ Piuthan, and Tansen areas. The maximum thickness of this formation varies from $150 \mathrm{~m}$. to $775 \mathrm{~m}$. However, the true thickness is not known since its upper limit is always truncated by a longitudinal thrust termed as Ranimatta/ Dubidanda Thrust (Table 1) in the type locality of the Surkhet /Dang areas, Western Nepal. The Suntar Formation is devoid of fossils with exception of fucoid markings and traces of worm burrows. Its lower contact with the underlying Swat Formation has an unconformity due to contrast lithology and erosion surface.

\section{GEOLOGICAL SETTING}

The tectonic set up of the Lower Tertiary rock of Nepal Himalaya is presented in the Table-1. A transect from south to north shows the following tectonic elements:

\section{Indo-Gangetic Plain (Terai)}

The Indo- Gangetic Plain is the fore- land of the Himalaya. It occupies a broad area that stretches from the Siwalik Fold Belt in the north to Indian Shicld in the south. Most of the basin lies in India, the portion falling within Nepal is termed as the Terai. 
Table 1 TECTONIC SET UP OF THE LOWER TERTIARY ROCKS OF NEPAL

South

Tectonic set up

I. Gangetic Plain (Tarai) Alluvium

- Main Frontal Thrust (MFT)

II. Autochthon Siwalik Group exposing the Upper Tertiary

sediments in the southern

foot hills.

Upper Siwalik

-------- Main Boundary Thrust

III. Para-autochthon Surkhet

Group exposing the Lower --- Unconformity----

Tertiary sediments with a dod Mani Formation

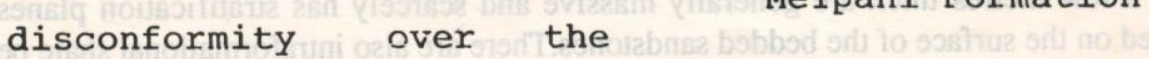

Metasediments of Mahabharat

Group.

Unconformity

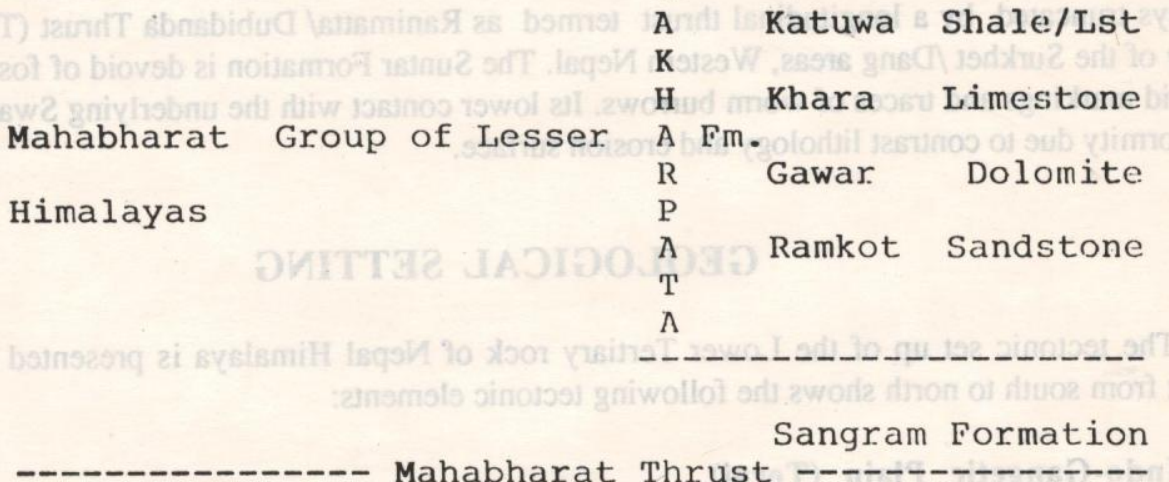

IV. Allochthon Midland Group

of Lesser II imalayas

Ranimatta /Dubid-

exposing metamorphic rocks.

anda Formation 


\section{Sub- Himalaya}

The Sub- Himalaya is termed as Churia Range in Nepal, rises abruptly from the Terai along the Main Frontal Thrust (MFT) and forms a series of ridges and valleys that are composed of thick beds of north dipping rocks (Siwaliks) which are thrusted and repeatedly folded. The Main Frontal Thrust (MFT) separates the Siwaliks from the Gangetic Plain (Terai) and forms the southern tectonic limit, while the Main Boundary Thrust (MBT) marks the nothern boundary.

\section{Lesser Himalaya}

The Lesser Himalaya is wide, geologically complex zone that lies immediately north of the Siwalik fold belt above the MBT and south of the Main Central Thrust (MCT) or the Higher Himalaya. This zone includes Lower Tertiary sediments of Para- autochthon Surket Group, the metasediments of Mahabharat Group and the low grade metamorphic rocks of Midland Group. The major rocks in the Midland include low grade metamorphics and basic igneous rocks of Proterozoic to Palaeozoic age. Ranimatta/ Dubidanda thrust usually separates the Midland Group with the metasediments of the Mahabharat Group. The Lower Tertiary sediments lie unconformably over the Lakharpata/ Sangram Formations of Mahabharat Group.

\section{DEPOSITIONAL ENVIRONMENT}

The sediments of Surkhet Group are represented by unfossilliferous Suntar, fossilliferous Swat and Melpani Formations. These seddiments lie unconformably over metasediments of the Mahabharat Group are affected by the Ranimatta thrust which has exposed low grade metamorphic rocks such as phyllites, quartzites and basic intrusives. Melpani Formation is composed of grey, dark grey, ferrugenous orthoquartzites and sandstones intercalated with grey, carbonaceous shales. The ferrugenous nature of the orthoquartzites and sandstones exhibit oxidising environment and its coarseness, well sorting and roundness of the grain shows that the sources of the deposited sediments were far enough. Further, thin sequences of grey shales indicate reducing environment, probably at that time, the sea water was withdrawn completely. Thus the sediments were unoxidised imparting black colour. This sequence is followed by the marine fossil bearing sediments of the Swat Formation. Broken fragments of shells suggest turbulent condition as well as transgression at the time of deposition. Thus the presence of larger foraminifera ( N. atacicus, A. subspinosa) in the sediments of Swat Formation suggests a shallow marine environment of deposition. Suntar sediments are grey to red, grish grey sandstones interbedded with grey to purple shales. Such rythmic deposition of grey to red sandstones and shales of Suntar Formation indicate the resultant cylindrical transgression and regression of the sea. Thus, only a slight, but variable thickness is attained along with frequent changes in oxidising environments. It also suggests that the sedimentary environment of the Suntar Formation could be of epicontinental type as well.

\section{AGE AND CORRELATION}

The Melpani Formation comprising orthoquartzites, sandstones and shales lies unconformably over the different members of the Lakharpata Formation and is overlain by the Swat Formation. Well preserved large foraminiferal fossils were identified at Surkhet, Dang/Piuthan, and Tansen area from limestone beds and lenses that are interbedded with carbonaceous shales of Swat Formation. The grey to grish grey shales of Swat Formation includes abundant gastropods and pelecypods. The presence of Nummulites beaumonti d"ARCHAIC and HEIME and Assilina papillata NUTTLE indicates Middle Eocene age (Sakai, 1983). In the 


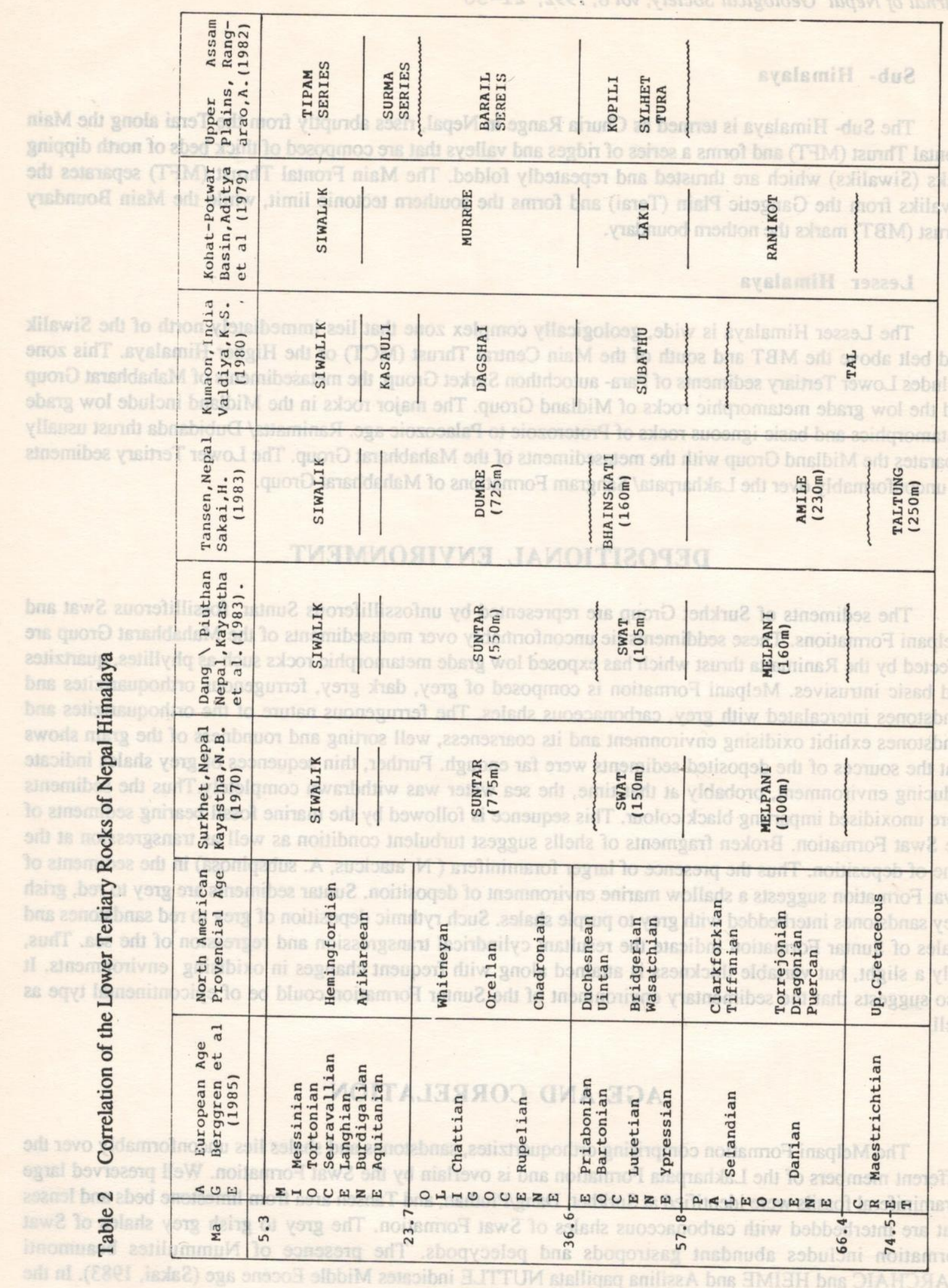

28 
Himalayan Range, fossiliferous Eocene beds are distributed discontinuously along the foothills of the Lesser Himalaya. In the Garhwal and Kumaon area, the Eocene beds called the Subathu are represented by a basal bed of pisolitic laterite and bauxite, pyritiferous shale with interbeds of coal and ironstone,grey and olive coloured shale and Nummulitic limestone with some olive shale in ascending order. This Subathu Formation has been arsigne on the basis of Nummulites and other larger foraminifera which occurred from limestones in the upper part (Valdiya, 1980). Thus it may be correlated with the Swat/ Melpani Formations due to similar lithofacies. The Suntar Formation comprising sandstones and purple shales is barren of fauna with exception of fucoid markings, worm burrows and plant remains. No fossils significant for age determination were obtained from the Suntar Formation. This formation is definitely younger than Swat Formation as overlies unconformably. The Suntar Formation is similar in lithofacies to Lower Murrees and Dagshai Formation of the Indian Himalayas. The Dagshai Formation comprises a series of grey or purplish, fine grained quartzitic sandstones with red to purplish brown, mottled clay interbedded. The sandstones are massive having poor stratification and gradually increase in proportion and thickness in the upper part. These features are entirely common to the Suntar Formation. Thus the Suntar Formation may be equivalent to Lower Murrees,Barail and Dagshai of Indian Himalayas presumed to be Oligocene - Early
Miocene in age.

\section{ACKOWLEDGEMENTS}

Permission to publish the article by the Petroleum Exploration Project, DMG, Kathmandu is gratefully acknowledged. Sincere thanks are due to Mr. U.M.S. Pradhan, Divisional Geologist and Mr. S.R. Sharma, Geologist for their kind cooperation and discussion during the preparation of this paper.

\section{REFERENCES}

Aditya,S., Raju, A.T.R. and Shukla,S.N. (1979): Assessment of hydrocarbon prospects of the SubHimalayan Punjab and Ganga Basins. Proc. Himalayan Geology Seminar, Sec.III, New Delhi, Misc. Publ. Geo. Surv., India. 1979, 41(5), pp 127-140.

Bashyal, R.P. (1986): Geology of Lesser Himalaya, Far Western Nepal Science de la Terre, Memoire 47, Nancy, France. pp 31- 42.

CPIT, (1973): Report on the investigation of Petroleum Geology in the Kingdom of Nepal, The chinese Petroleum Investigation Team, Beijing, China.

Dhital, M.R. and Kizaki, K. (1987): Lithology and Stratigraphy of the Northern Dang, Lesser Himalaya. Publ., Bulletin of the College of Science, University of the Ryukyus, Okinawa, Japan. No. 45, pp 183-244.

Gansser, A. (1964): Geology of the Himalayas. John Wiley and Sons, London, pp-289. Hashimoto, S., Ohta, Y and Akiba, Ch. (Eds.). (1973): Geology of the Nepal Himalayas. Saikon Publ. Tokyo, pp 292. Kayastha, N.B. (1970): The Geology of Nepalgunj- Surkhet Area in Western Nepal, Unpubl., Geol. Surv.
of Nepal, pp 32. 
Kayastha, N.B. and Aryal, R.K. (1976): Geology of Sunauli- Pokhara Highway, Unpubl., Geol.Surv.of Nepal, pp 14.

Kayastha, N.B. and Shrestha, R.B.(1982): Report on Detailed Geological Sectons of Dang/Puithan Area, Far Western Nepal, Unpul., Dept. of Mines \& Geology, Kathmandu, pp 36.

Kayastha, N.B. (1982): Chure Surkhet Basin, Nepal, ESCAP ATLAS OF STRATIGRAPHY III, Vol. VIII, NO.48, pp 113- 114, United Nations Publication, New York.

Kayastha, N.B. and Pradhan, U.M.S. (1983): Contribution to Project No.32, Stratigraphic Correlations betw Sedimentary Basins in the ESCAP Region, Nepal National Committee for UNESCO Geological Correlation Programme, Kathmandu, pp-18.

Kayastha, N.B. and et.al. (1983): Report on Detailed Geological Sections of Dang/ Rolpa Area, Western Nepal. Unpubl., PEPP/ DMG, Kathmandu. pp 25.

Matsumaru, K. and Sakai, H.(1989): Nummulites and Assilina from Tansen area, Palpa District, The Nepal Lesser Himalayas.Trans. Proc. Palaeont. Soc. Japan, N. S. No. 154, Tokyo, Japan. pp 68-76.

Ranga Rao, A.(1982): Geology and Hydrocarbon potential of a part of Assam - Arakan Basin and its adjacent region, in Petroliferous Basins of India -I, Petroleum Asia Journal, pp 127-158.

Sakai, H. (1983): Geology of the Tansen Group of the Lesser Himalaya in Nepal, Mem. Fac. Sci., Kyushu Univ., Ser.D.Geol., Vol.xxv, No.1, Fukuoka, Japan. pp 27-74.

Sharma, C. K.(1990): Geology of Nepal Himalaya and adjacent countries. Publ. Bisal Nagar, Kathmandu, Nepal. pp 479.

Tater, J.M., Kayastha, N.B. and et. al (1982): Geological map of Nepal. Scale 1:100,000, DMG., Nepal, Prin.,Tolworth, Surrey, England.

Tater, J.M., Kayastha, N.B. and Murphy, R.W.(1989): Nepal opens a second Bidding Round; Nepal offering Seismic Survey of Eastern Block: Oil anbd Gas Journal, March 13 and 20,1989.

Valdiya, K.S.(1980): Geology of Kumaun Lesser Himalaya. Wadia Institute of Himalayan Geology, Dehradun, India, pp 291. 